\title{
ANALISIS TREND PENETASAN TELUR NYAMUK Aedes $s p$ BERDASARKAN DERET WAKTU DI KELURAHAN TELUK KECAMATAN PURWOKERTO SELATAN KABUPATEN BANYUMAS TAHUN 2017
}

\author{
Kurnia Saraswati ${ }^{*}$, Aris Santjaka**) \\ Jurusan Kesehatan Lingkungan, Politeknik Kesehatan Kemenkes Semarang, \\ Jl.Raya Baturaden KM 12 Purwokerto, Indonesia
}

\begin{abstract}
Abstrak
Pelaksanaan fogging foccus bertujuan untuk membasmi vektor Aedes sp serta memutus mata rantai penularannya . Fogging foccus dilaksanakan dua kali dengan interval waktu 7 hari. Fogging foccus didasarkan pada teori siklus perkembangbiakan nyamuk dari jentik ke nyamuk dewasa kurang lebih 7 hari. Apakah proses perkembangbiakan nyamuk dari telur sampai dewasa paling banyak terjadi pada 7 hari atau lebih. Tujuan penelitian adalah mengetahui persentase terbesar mulai dari telur menjadi nyamuk dewasa guna dibandingkan dengan efektifitas fogging foccus. Jenis penelitian adalah penelitian observasional menggunakan trend series dengan 3 siklus aquatic sebanyak 100 telur yang ditetaskan selama 21 hari. Hasil penelitian menunjukkan bahwa waktu yang diperlukan untuk telur sampai menjadi nyamuk dewasa adalah 2-10 hari. Pada suhu rendah perkembangannya bisa sangat lama yaitu berkisar 2-18 hari. Persentase penetasan telur yang dilakukan di rumah peneliti di Kelurahan Kober yaitu sebesar 75\%. Sedangkan yang dilakukan di Laboratorium Kampus 7 Poltekkes Kemenkes Semarang sebesar 90\%. Hasil di Kelurahan Kober siklus aquatic 1 belum ada yang menjadi nyamuk dewasa, siklus aquatic 2 sebanyak 14,67\%, siklus aquatic 3 sebanyak 30,67\%. Hasil di laboratorium Kampus 7 Poltekkes Kemenkes Semarang pada siklus aquatic 1 dan siklus aquatic 2 belum ada yang menjadi nyamuk dewasa, pada siklus aquatic 3 sebanyak 3,33\%. Adapun kondisi lingkungan pada saat penelitian yaitu suhu udara $27^{\circ} \mathrm{C}-30^{\circ} \mathrm{C}$ dan kelembaban $70 \%-90 \%$.

Simpulan penelitian yaitu pelaksanaan fogging foccus yang dilakukan dalam dua tahapi dengan interval waktu 7 hari didasarkan siklus aquatic ternyata larva belum menjadi nyamuk dewasa sehingga fogging yang dilakukan akan kurang efektif dan belum tepat pada sasaran yaitu membunuh nyamuk dewasa.
\end{abstract}

Kata kunci: ovitrap; rearing; persentase penetasan telur; kesehatan lingkungan

\begin{abstract}
[Analysis of Hatching Trend of Aedes sp Mosquito Eggs Based on Time Sequences in Teluk Subdistrict of South Purwokerto District of Banyumas Regency on 2017] Foccus fogging is aimed to eradicate mosquito vector aedes sp as well as breaking the chain of its transmission. Fogging is conducted twice with the interval time 7 days. Fogging foccus is based on cycle theory of mosquito breeding adult mosquito larvae into less more 7 days. It is the process of mosquito breeding from eggs to adult fence many happen in 7 days or more. The Objective is to know the largest percentation starting from egg to adult mosquito compared the with effectiveness of fogging focus. This research is an observational research trends using series with 3 cycle water as much as 100 eggs hatches for 21 days. The results showed that the time required to review the eggs until it became an adult mosquito is 2-10 days. At the low temperature, its development can be very long it is ranged from 2-18 days. Percentage of egg hatching done at home researchers in kober village equal to $75 \%$. While conducted at the campus laboratory 7 poltekkes kemenkes semarang is $90 \%$. Results in kober village, in water cycle 1 no one has become adult mosquitoes, while in water cycle 2 as much as $14.67 \%$, and water cycle 3 as much as 30.67\%. Results of laboratory campus 7 on polytechnic of semarang both in water cycle 1 and cycle water 2 no one has become adult mosquitoes, on cycle 3 water as much as $3.33 \%$. It was done for environmental conditions at the time that temperature air is $27{ }^{\circ} \mathrm{C}-30{ }^{\circ} \mathrm{c}$ and humidity $70 \%-90 \%$. The research conclusions prove that the hatching of mosquito eggs is 2-10 days then it needs evaluation of the implementation of the mass fogging or fogging foccus with interval time 7 days, because in 7 the mosquitos have not being adult mosquitos yet so the fogging will be less effective, so the purpose of fogging that killing adult mosquitoes is really right on target.
\end{abstract}

Keywords: ovitrap; rearing; Fg hatching egg; environtmental health 
1. Pendahuluan: Permenkes RI No 374/MENKES/PER/III/2010 Bab 1 pasal 1 (2) pengendalian vector adalah semua kegiatan atau tindakan yang ditujukan untuk menurunkan populasi vector serendah mungkin, sehingga keberadaannya tidak lagi berisiko untuk terjadinya penularan penyakit yang disebabkan oleh vector disuatu wilayah, sehingga penularan penyakit yang disebabkan oleh vector dapat dicegah. Salah satu penyakit yang ditularkan oleh vector nyamuk Aedes aegypti adalah Demam Berdarah Dengue (DBD). Nyamuk Aedes aegypti merupakan jenis nyamuk yang dapat membawa virus Dengue penyebab penyakit demam berdarah. Sebagai pembawa virus Dengue, Aedes aegypti merupakan vector utama (Primary vector) bersama dengan Aedes albopictus menciptakan siklus persebaran Dengue didesa dan kota.

Serangan penyakit DBD pertama kali dilaporkan pada tahun 1897. Serta di Italia dan Taiwan pada tahun 1931. Selama dua puluh tahun kemudian, terjadi peningkatan kasus dan wilayah penyebaran DBD yang luar biasa hebatnya, dan saat ini KLB muncul setiap tahunnya di beberapa negara di Asia Tenggara termasuk Indonesia.

Sejak tahun 1968 penyakit ini ditemukan di Surabaya dan Jakarta, selanjutnya sering terjadi kejadian luar biasa dan meluas ke seantero wilayah Republik Indonesia. Oleh karena itu, penyakit ini menjadi masalah kesehatan masyarakat yang awalnya banyak menyerang anak tetapi akhir-akhir ini menunjukkan pergeseran menyerang dewasa.(Soegeng Soegijanto, 2006).

Awal kejadian luar biasa penyakit virus Dengue setiap lima tahun selanjutnya mengalami perubahan menjadi tiga tahun, dua tahun, dan akhirnya setiap tahun diikuti dengan adanya kecenderungan peningkatan infeksi virus Dengue pada bulan-bulan tertentu.

Data Direktorat Pengendalian Penyakit Tular Vektor dan Zoonosis Kementerian Kesehatan menyebutkan hingga akhir Januari tahun ini, kejadian luar biasa (KLB) penyakit DBD dilaporkan ada di 12 Kabupaten dan 3 Kota dari 11 Provinsi di Indonesia, dengan Kabupaten Banyumas menempati urutan nomor 10 .

Angka kesakitan/Incidence Rate (IR) di Kabupaten Banyumas pada tahun 2016 sebesar 20/100.000 penduduk. Angka IR DBD Kabupaten Banyumas tahun 2016 mengalami peningkatan dibanding tahun 2015. Sedangkan angka kematian/Case Fatality Rate (CFR) pada tahun 2016 adalah sebanyak 15 orang mengalami peningkatan dibanding tahun 2015 kematiannya sebanyak 1 orang. Tahun 2012 kasus DBD sebanyak 200 kasus, dan mengalami peningkatan pada tahun 2013 sebanyak 543 kasus, lalu ditahun 2014 mengalami penurunan menjadi 209 kasus, namun pada tahun 2015 mengalami peningkatan kembali sebanyak 264 kasus, dan meningkat kembali secara signifikan pada tahun

\footnotetext{
${ }^{*}$ E-mail: kurniasaraswati19@gmail.com

${ }^{* *}$ E-mail: arissantjaka@gmail.com
}

2016 tercatat dari bulan Januari sampai Oktober sudah terjadi sebanyak 1.281 kasus. (DKK Banyumas, 2016).

Data Dinas Kesehatan Kabupaten Banyumas pada tahun 2016 mengenai angka kejadian DBD, menempatkan wilayah kerja Purwokerto Selatan sebagai wilayah tertinggi kasus DBD dari tahun 20132016 dengan jumlah sebesar 35 kasus pada tahun 2013, 18 kasus pada tahun 2014, 63 kasus pada tahun 2015, dan sebesar 93 kasus yang tercatat sampai bulan Oktober pada tahun 2016. Wilayah kerja Puskesmas Purwokerto Selatan 2016 masih ditemukan kasus DBD dengan jumlah sebanyak 23 kasus di Desa Teluk, 11 kasus di Desa Karang Klesem, 9 kasus di Desa Berkoh, sebanyak 6 kasus di Desa Purwokerto Kidul, sebanyak 7 kasus di Desa Purwokerto Kulon, sebanyak 27 kasus di Desa Tanjung, serta tercatat sebanyak 16 kasus di Desa Karang Pucung. Puncak kasus DBD terbanyak terjadi pada bulan Februari hingga Maret. Dengan data Dinas Kesehatan Kabupaten Banyumas tersebut menempatkan wilayah Desa Teluk dengan kasus DBD tertinggi pada tahun 2013-2016 di Kecamatan Purwokerto Selatan (DKK Banyumas, 2016)

Kasus DBD yang terjadi seringkali dikaitkan dengan pelaksanaan fogging atau pengasapan yang bertujuan untuk membasmi vektor Aedes sp serta memutus mata rantai penularannya. Fogging yang dikenal selama ini dan diterapkan di masyarakat berupa fogging masal dan fogging focus. Fogging focus dilakukan dalam radius kurang lebih 100-200 meter dari indeks kasus kejadian penderita DBD.

Hasil penelitian Irawan Endy Pratama tentang Evaluasi Nyamuk Dewasa Setelah Pelaksanaan Fogging Focus Di Desa Sidamulih Kecamatan Rawalo Kabupaten Banyumas Tahun 2016 yaitu penangkapan nyamuk yang dilakukan dengan cara menarik garis lurus 200 meter ke utara, selatan, barat dan timur dari 2 rumah indeks kasus, penangkapan nyamuk yang dilakukan adalah dengan cara berkala mengikuti umur perkembangan nyamuk. Satu hari sebelum fogging focus I dilakukan penangkapan nyamuk dan didapatkan 57 ekor nyamuk, 3 hari setelah fogging focus I didapatkan sebanyak 34 nyamuk, 3 hari setelah fogging focus II sebanyak 63 ekor nyamuk, 10 hari setelah fogging foccus II sebanyak 93 ekor nyamuk, dan 17 hari setelah fogging foccus II didapatkan sebanyak 112 ekor nyamuk. Penangkapan nyamuk yang di lakukan dengan mengikuti perkembangan umur nyamuk dimulai dari sebelum pelaksanaan fogging focus I sampai dengan 17 hari setelah pelaksanaan fogging focus II mengalami fluktuasi, dan cenderung meningkat bahkan setelah dilakukan fogging foccus. Hal ini menunjukkan bahwa fogging foccus bisa di katakan tidak mempengaruhi densitas nyamuk dewasa. Salah satu upaya untuk melihat dan mengamati tingkat kepadatan alami nyamuk Aedes sp yaitu menggunakan ovitrap. Peneliti mengharapkan mendapatkan telur nyamuk pada ovitrap yang dipasang pada beberapa rumah penderita DBD yang 
sebelumnya telah disebutkan pada data di Puskesmas Purwokerto Selatan kemudian akan menganalisis kecenderungan penetasan telur hingga menjadi nyamuk dewasa.

Penelitian ini bertujuan untuk mengetahui apakah telur nyamuk yang didapatkan pada ovistrip yang dipasang pada ovitrap di rumah penderita secara keseluruhan menetas dalam waktu 7 hari dengan asumsi bahwa dalam 7 hari telur sudah menetas menjadi nyamuk dewasa, jika selama satu minggu proporsi menetas tidak terlalu besar berarti fogging foccus tahap ke dua kurang efektif membunuh nyamuk Aedes aegypti. Informasi tentang trend waktu penetasan telur guna dibandingkan dengan kegiatan fogging belum banyak diketahui, maka peneliti ingin melakukan percobaan yang berjudul Analisis Trend Penetasan Telur Nyamuk Aedes sp Berdasarkan Deret Waktu Di Kelurahan Teluk Kecamatan Purwokerto Selatan Kabupaten Banyumas Tahun 2017.

\section{Tujuan}

Khusus

a. Mendeskripsikan kondisi lingkungan yang meliputi suhu udara, kelembaban udara, dan daya tarik tempat-tempat untuk berkembangbiak dan tempat istirahat nyamuk Aedes $s p$.

b. Membandingkan 2 tempat berbeda yang digunakan untuk proses rearing telur Aedes sp.

c. Mendeskripsikan suhu air, $\mathrm{pH}$ air perindukkan, serta kelembaban yang mempengaruhi pertumbuhan dan perkembangan larva dan daya tetas telur Aedes sp.

d. Menghitung jumlah telur nyamuk Aedes sp dan menetaskannya hingga menjadi nyamuk dewasa dalam 3 siklus aquatic.

e. Analisis trend jumlah telur nyamuk yang menetas menjadi nyamuk dewasa pada satu siklus aquatic sampai 3 kali siklus aquatic.

\section{Manfaat}

a. Bagi Masyarakat

Pengetahuan dan informasi tentang rentang waktu yang diperlukan nyamuk dari telur hingga menjadi nyamuk dewasa, sehingga dapat mengupayakan pencegahan perkembangan nyamuk.

b. Bagi Instansi / Pemerintah

Membantu dalam menangani masalah kesehatan atau penyakit yang diakibatkan oleh vektor nyamuk.

c. Bagi Almamater

Bahan kepustakaan dan bahan ajar atau referensi penelitian eksperimen tentang analisis trend penetasan telur nyamuk bagi Politeknik Kesehatan Kemenkes Semarang Jurusan Kesehatan Lingkungan Purwokerto.

d. Bagi Peneliti

Informasi dan tambahan pengetahuan tentang waktu penetasan telur nyamuk Aedes aegypti hingga menjadi nyamuk dewasa serta tambahan pengetahuan dalam bidang pengendalian vektor.

\section{Bahan dan Metode}

Tempat dan Waktu Penelitian

Penelitian ini dilakukan di Laboratorium Kampus 7 Poltekkes Kemenkes Semarang dan di Kelurahan Kober pada tahun 2017.

\section{Bahan dan Alat}

Bahan yang digunakan dalam penelitian ini adalah telur Aedes sp yang didapatkan dari ovistrip pada ovitrap yang dipasang di Perumahan Teluk Jalan Aksia Raya RT 04/RW 09 Kelurahan Teluk Kecamatan Purwokerto Selatan Kabupaten Banyumas. Sedangkan alat yang digunakan adalah nampan plastik, pipet jentik, beaker glass, dan kurungan nyamuk.

\section{Cara Kerja}

\section{Pemasangan Ovitrap}

Penelitian dilakukan di Kelurahan Teluk Kecamatan Purwokerto Selatan pada Perumahan Teluk yaitu Jl. Akasia Raya RT 04 RW 09 dengan mengambil 20 rumah sebagai lokasi sampel yang ditarik garis lurus sepanjang 200 meter ke utara, selatan, barat dan timur dari 2 rumah indeks kasusdan dilakukan pemasangan ovitrap sebanyak 60 ovitrap. Setiap rumah dilakukan pemasangan tiga buah ovitrap, dua buah di dalam rumah dan satu buah di luar rumah dengan mengambil titik pemasangan ovitrap pada tempat-tempat yang sering dilakukan aktifitas sehari-hari oleh anggota keluarga. Pemasangan ovitrap di dalam rumah yaitu di ruang tamu ata uruang keluarga dan dekat kamar mandi, sedangkan ovitrap diluar rumah dipasang pada halaman rumah yang didekat tanaman dan barangbarang bekas.

Pemasangan dilaksanakan selama 7 hari dimana setiap dua hari setelah pemasangan, dilakukan pengecekan dan pengambilan telur yang sudah terdapat dalam ovitrap lalu dilanjutkan pemasangan sampai hari ke tujuh.

\section{Penetasan telur Aedes sp}

Telur yang didapatkan pada ovistrip kemudian dihitung sebanyak 100 butir untuk kemudian dilakukan perendaman pada air perindukan yang sudah diukur suhunya terlebih dahulu. Proses rearing dari mulai perendaman telur yang dilakukan pada nampan plastik sampai telur berubah menjadi pupa kemudian dipindahkan dalam beaker glass yang dimasukkan ke dalam kurungan nyamuk hingga menjadi nyamuk dewasa dilakukan selama 21 hari atau selama 3 siklus aquatic.

\section{Hasil dan Pembahasan \\ Gambaran Umum}

Kelurahan Teluk merupakan wilayah Kecamatan Purwokerto Selatan Kabupaten Banyumas Provinsi Jawa Tengah, dengan luas wilayah 1375,31 Ha atau $3.51 \mathrm{Km}^{2}$. Kelurahan Teluk terdiri dari $97 \mathrm{RT}$ dan sebanyak 17 RW. Kelurahan Teluk memiliki jumlah 
penduduk sebanyak 17.828 jiwa dengan Kepadatan Penduduk sebesar 4.901 jiwa $/ \mathrm{km}^{2}$ termasuk kategori sangat tinggi ( $>1.200 \mathrm{jiwa} / \mathrm{km}^{2}$ ). Kelurahan Teluk dengan jumlah penduduk laki-laki sebanyak 8.995 jiwa dan jumlah penduduk perempuan sebanyak 8.833 jiwa. Persentase antara laki-laki dan perempuan yaitu laki-laki $10.58 \%$ dan perempuan $10.47 \%$. Jumlah Kepala Keluarga/KK di Kelurahan Teluk sebanyak 5.498 KK. Penelitian yang dilakukan di Perumahan Teluk Jalan Akasia Raya RT 04 RW 09 Kelurahan Teluk Kecamatan Purwokerto Selatan jarak antar rumah yaitu \pm 100 meter dengan kepadatan penduduk yang termasuk dalam ketgori sangat tinggi memungkinkan untuk terjadinya penularan penyakit DBD yang disebabkan oleh vektor Aedes sp. Jarak terbang nyamuk yang diperkirakan 10-100 meter (Depkes RI,2007), maka peneliti mengambil sampel sebanyak 20 rumah yang berdekatan dengan 2 indeks kasus DBD di tahun 2016.

\section{Gambaran Khusus}

\section{Indeks Ovitrap}

Pemasangan sejumlah 60 ovitrap pada 20 rumah sampel dengan hasil ovitrap positif sebanyak 52 ovitrap dan 8 ovitrap negatif atau sebesar $86,67 \%$ ovitrap positif dan sebanyak 13,33\% ovitrap negatif.

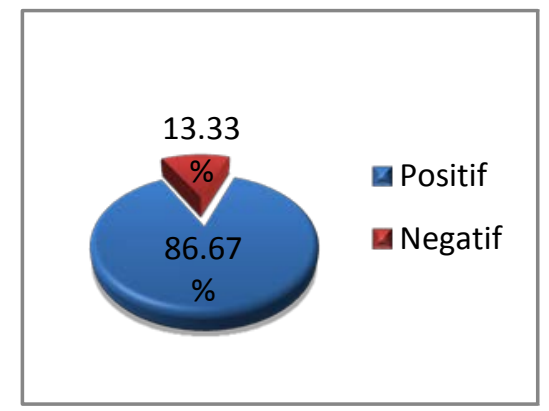

Gambar 1. Persentase Indeks Ovitrap

Pemasangan Ovitrap dilakukan di dalam dan di luar rumah. Sebanyak 40 buah ovitrap yang dipasang di dalam rumah dan sebanyak 20 ovitrap yang dipasang di luar rumah. Sebanyak 17 ovitrap atau sebesar 85\% yang dipasang diluar rumah positif telur dan

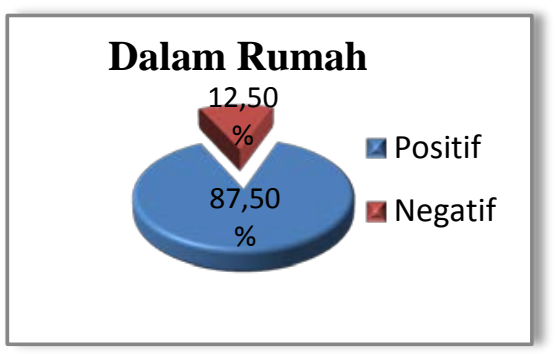

Gambar 2. Persentasae ovitrap di dalam rumah

Sebanyak 35 ovitrap dari 40 ovitrap yang dipasang atau sebesar $87,5 \%$ positif telur yang dipasang di dalam rumah dan yang negatif sebanyak 5 ovitrap atau sebesar $12,50 \%$.

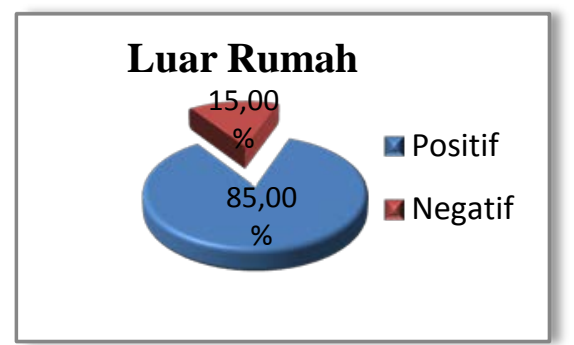

Gambar 3. Persentasae ovitrap di luar rumah

Sebanyak 17 ovitrap dari 20 ovitrap yang dipasang atau sebesar $85 \%$ positif telur yang dipasang di dalam rumah dan yang negatif sebanyak 3 ovitrap atau sebesar $15 \%$.

\section{Daya Tetas Telur}

Proses rearing dari fase telur sampai menjadi nyamuk dewasa berlangsung selama 21 hari dengan rata-rata suhu antara $28,8^{\circ} \mathrm{C}-29,5^{\circ} \mathrm{C}$ dan kelembaban 72,27\%-89\%. Pada proses rearing di Laboratorium Kampus 7 Poltekkes Kemenkes Semarang jumlah telur dari 100 butir yang menetas sebanyak 90 butir dan menetas pada hari keempat setelah perendaman telur. Sedangkan pada proses rearing yang dilakukan di Kelurahan Kober Kecamatan Purwokerto Barat dari 100 butir telur yang menetas adalah sebanyak 75 butir pada hari kedua setelah perendaman telur. Setelah menetas pada hari kedua dan hari keempat tidak ditemukan lagi telur yang menetas selama proses rearing yang dilakukan.

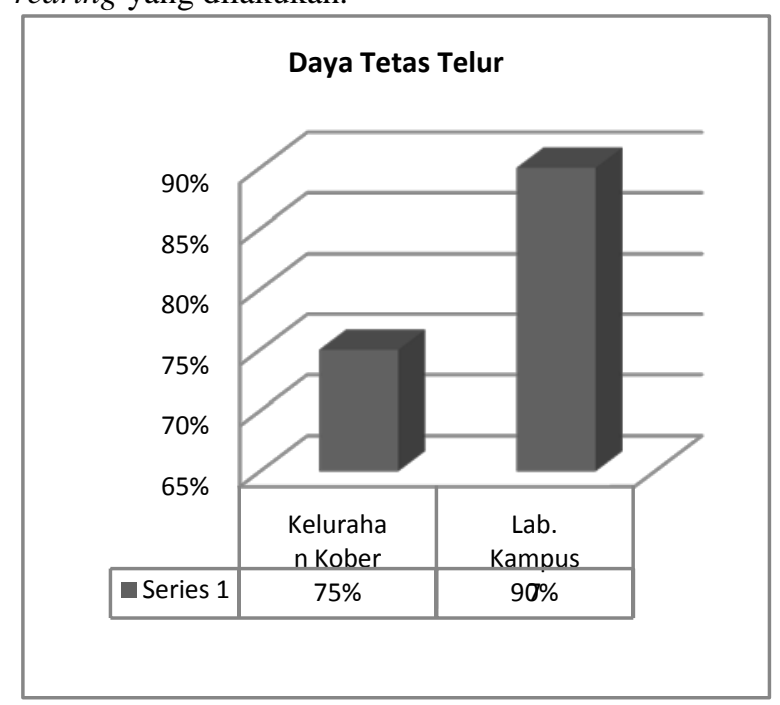

Gambar 4. Persentasae daya tetas telur

Persentase Telur nyamuk yang menetas di rumah peneliti di Kelurahan Kober yaitu sebesar 75\%, sisanya sebanyak 25\% tidak menetas sampai dengan hari ke 21. Sedangkan persentase telur nyamuk yang menetas di Laboratorium Kampus 7 Poltekkes Kemenkes Semarang sebesar 90\%, sisanya sebanyak $10 \%$ tidak menetas sampai dengan hari ke 21 .

Jumlah telur dipengaruhi oleh umur nyamuk, semakin tua umur nyamuk betina jumlah telur semakin sedikit, sedangkan daya tetas telur nyamuk Aedes aegypti dipengaruhi oleh waktu simpan atau 
lama penyimpanan telur karena semakin lama telur disimpan daya tetas telur semakin menurun. Faktor lain yang mempengaruhi daya tetas telur Aedes sp yaitu lama penetasan dalam siklus hidup tergantung pada waktu yang dibutuhkan telur untuk menjadi masak sesudah telur ditelurkan oleh induknya dan juga bergantung pada temperatur masa perkembangan selanjutnya serta kemungkinan adanya telur yang tidak dibuahi (infertil).

\section{Pertumbuhan Larva}

Proses rearing di Kelurahan Kober Perkembangan larva dari Instar I sampai Instar IV memerlukan waktu kurang lebih 2-8 hari dan dari Instar IV menjadi pupa memerlukan waktu 1-2 hari. Satu siklus aquatic yaitu satu minggu (7 hari) secara teoritis telur nyamuk sudah menjadi nyamuk dewasa pada hari ke 7 , tetapi hasil penelitian menunjukkan pada siklus aquatic 1yaitu pada hari ke 7 telur nyamuk sampai dengan fase Instar III yang berjumlah 9 jentik atau sebesar $12 \%$, pada siklus aquatic 2 yaitu pada hari ke 14 hanya terdapat 3 jentik atau sebesar 5,33\% pada Instar IV dan terdapat 2 pupa. Siklus aquatic 3 pada hari ke 21 terdapat 31 jentik pada Instar IV dan terdapat sebanyak 21 pupa, secara keseluruhan berubah menjadi pupa pada hari ke 23 melebihi dari 3 siklus aquatic.Sedangkan perkembangan larva dari Instar I sampai Instar IV memerlukan waktu kurang lebih 4-14 hari dan dari Instar IV menjadi pupa memerlukan waktu 1-2 hari di Laboratorium Kampus 7 Poltekkes Kemenkes Semarang. Pada siklus aquatic 1 yaitu pada hari ke 7 hanya sampai dengan Instar II sebanyak 4 jentik atau sebesar 4,44\% dan Instar I sebanyak 86 jentikatau sebesar 95,55\%, pada siklus aquatic 2 yaitu pada hari ke 14 hanya sampai dengan Instar IV sebanyak 2 jentik atau sebesar 2,22\% dan belum ada yang menjadi nyamuk dewasa. Pada siklus aquatic 3 yaitu pada hari ke 21 sampai dengan insyat IV sebanyak 55 atau sebesar 61,11\% dan sebanyak 25 pupa atau sebesar $27,77 \%$.

\section{Dewasa \\ Pertumbuhan Pupa sampai Nyamuk \\ Proses rearing dari pupa hingga menjadi} nyamuk dewasa yang dilakukan di Kelurahan kober memerlukan waktu 1-2 hari. Pada hari ke 8 dari Instar IV sebanyak 9 jentik kemudian menjadi pupa pada hari ke 9 sebanyak 9 pupa atau sebesar $12 \%$. Kemudian berubah menjadi nyamuk pada hari ke 10 sebanyak 9 ekor nyamuk. Pada hari ke 10 dari Instar IV yang menjadi pupa sebanyak 1 pupa, kemudian menjadi nyamuk pada hari ke 11 sebanyak 10 ekor nyamuk atau sebesar 13,33\%. Pada hari ke 12 terdapat 1 pupa kemudian berubah menjadi nyamuk pada hari ke 13 sehingga jumlah nyamuk menjadi 11 ekor. Pada hari ke 14 terdapat 2 pupa dan bertambah menjadi 4 pupa pada hari ke 15 menjadi 4 pupa, berubah menjadi nyamuk pada hari ke 16 sehingga bertambah menjadi 15 ekor nyamuk atau sebesar 20\%. Pada hari ke 19 terdapat 4 pupa dan 18 ekor nyamuk. Pada hari ke 20 sebanyak 20 ekor nyamuk dan pada hari ke 21 terdapat sebanyak 21 pupa dan 23 ekor nyamuk. Pada hari ke 21 tercatat sebanyak 31 larva Instar IV, 21 pupa, dan 23 ekor nyamuk atau sebesar 30,67\%.

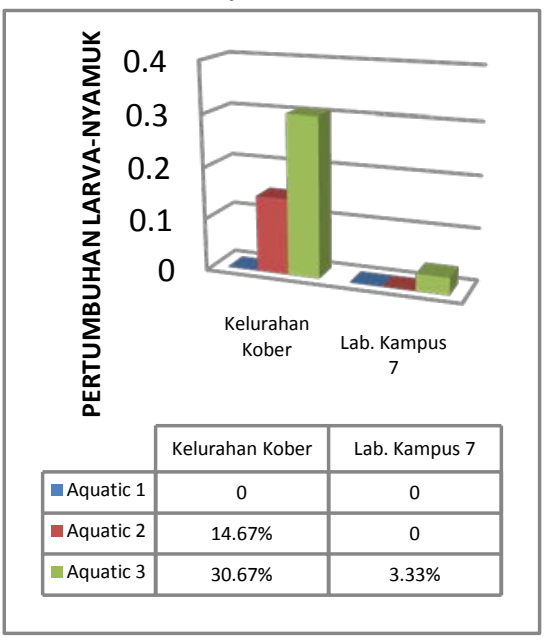

Gambar 5. Pertumbuhan Larva-Nyamuk

Proses rearing dari pupa hingga menjadi nyamuk dewasa yang dilakukan di Laboratorium Kampus 7 Poltekkes Kemenkes Semarang memerlukan waktu 1-2 hari. Pertumbuhan pupa sampai menjadi nyamuk dewasa pada proses rearing yang dilakukan di Laboratorium Kampus 7 Poltekkes Kemenkes Semarang baru terdapat pupa pada hari ke 14 yaitu sebanyak 2 pupa, kemudian berubah menjadi nyamuk pada hari ke 18 atau sebesar 2,22\%. Pada hari ke 19 terdapat 1 pupa yang kemudian berubah menjadi nyamuk pada hari ke 21 sehingga terdapat sebanyak 3 ekor nyamuk atau sebesar 3,33\%. Jadi pada hari ke 21 terdapat sebanyak 7 larva Instar III, 55 larva Instar IV, 25 pupa, dan sebanyak 3 ekor nyamuk.

Soegeng Soegijanto (2006) menyatakan suhu media tempat perindukan yang optimal berkisar antara $25-27^{\circ} \mathrm{C}$ merupakan keadaan optimal untuk perkembangan larva nyamuk Aedes sp. pH air media tempat perindukan juga mempengaruhi perkembangan larva dan kepadatan larva serta adanya predator. Pada Laboratorium Kampus 7 Poltekkes Kemenkes Semarang terletak di dataran tinggi, yang suhu udaranya rendah dan kelembaban tinggi. Pada malam hari suhu udara dapat mencapai $23^{\circ} \mathrm{C}$ hal ini dapat berpengaruh terhadap perkembangan larva nyamuk Aedes sp dan menyebabkan proses perkembangan menjadi nyamuk dewasa terhambat. Penelitian Hallimuddin (1997) menyatakan bahwa Perkembangan nyamuk Aedes aegypti terutama larvanya dipengaruhi oleh makanan yang terdapat pada media tertama mikroorganisme yaitu bakteri dan spora jamur.

\section{Kesimpulan dan Saran \\ Kesimpulan}

Berdasarkan penelitian yang telah dilakukan tentang Analisis Trend Penetasan Telur Nyamuk Aedes sp Berdasarkan Deret Waktu Di Kelurahan 
Teluk Kecamatan Purwokerto Selatan Kabupaten Banyumas Tahun 2017 didapatkan data sebagai berikut :

1. Hasil penelitian menunjukkan bahwa waktu yang diperlukan untuk telur sampai menjadi nyamuk dewasa tidak sama dengan 7 hari. Faktanya telur baru berubah menjadi nyamuk dewasa dalam 10 hari. Daya tetas telur di Kelurahan kober dari 100 butir telur yang menetas sebanyak 75\%, sedangkan di Laboratorium Kampus 7 Poltekkes Kemenkes Semarang dari 100 butir telur menetas sebanyak 90\%.

2. Telur secara keseluruhan menjadi nyamuk dewasa dalam waktu 23 hari pada proses rearing dengan suhu $27^{\circ} \mathrm{C}-30^{\circ} \mathrm{C}$ dan kelembaban $70 \%-90 \%$.

3. Hasil penelitian di Kelurahan Kober pada siklus aquatic 1 belum terdapat nyamuk dewasa, pada silus aquatic 2 terdapat sebanyak 14,67\% yang telah menjadi nyamuk, pada siklus aquatic 3 terdapat sebanyak 30,67\% yang berubah menjadi nyamuk dewasa. Penelitian yang dilakukan di Laboratorium Kampus 7 pada siklus aquatic 1 dan siklus aquatic 2 belum ada yang menjadi nyamuk dewasa, dan pada siklus aquatic 3 terdapat sebanyak 3,33\% yang telah menjadi nyamuk dewasa. Telur paling banyak menjadi nyamuk dewasa pertama kali pada hari ke 10 yaitu sebanyak $12 \%$.

\section{Saran}

Dengan dibuktikan bahwa penetasan telur nyamuk adalah 2-10 hari maka perlu evaluasi terhadap pelaksanaan fogging masal maupun fogging foccus yang dilakukan dalam 2 tahap dengan rentang waktu 7 hari, karena dalam waktu 7 hari larva belum menjadi nyamuk dewasa. Untuk Jajaran Kesehatan perlu dipertimbangkan pelaksanaan fogging foccus tahap ke dua yaitu tidak lagi selama 1 siklus aquatic atau 7 hari tetapi 10 hari.

\section{Ucapan Terima Kasih}

Alhamdulillahirobbil'alamin, Puji syukur kehadirat Allah SWT yang telah memberikan rahmat, hidayah dan karunia-Nya, sehingga penulis dapat menyelesaikan Karya Tulis Ilmiah yang berjudul "Analisis Trend Penetasan Telur Nyamuk Aedes sp Berdasarkan Deret Waktu DiKelurahan Teluk Kecamatan Purwokerto Selatan Kabupaten BanyumasTahun 2017“

Dalam penyelesaian penulisan Karya Tulis Ilmiah ini penulis mendapatkan banyak bantuan dari berbagai pihak baik bantuan moril maupun materil, oleh karena itu penulis mengucapkan terima kasih kepada :

1. Bapak Sugiyanto, S.Pd, M.App, Sc., selaku Direktur Politeknik Kesehatan Kemenkes Semarang.

2. Bapak Asep Tata Gunawan, S.K.M., M.Kes.,selaku Ketua Jurusan Kesehatan Lingkungan Purwokerto.

3. Bapak Suparmin, S.S.T., M.Kes., selaku Ketua Program Studi Diploma III Jurusan Kesehatan Lingkungan Purwokerto.

4. Bapak Aris Santjaka, S.K.M., M.Kes., selaku pembimbing Karya Tulis Ilmiah yang telah memberikan banyak motivasi, saran dan masukan.

5. Bapak Budi Utomo, SKM, M.Kes., selaku penguji I yang telah memberikan saran dan masukan.

6. Teguh Widiyanto, S.Sos, M.Kes.,selaku penguji II yang telah memberikan saran dan masukan.

7. Seluruh dosen dan staf Program Studi D-III Kesehatan Lingkungan Purwokerto yang telah membantu kelancaran proses penulisan karya tulis ilmiah ini.

Penyusun menyadari bahwa masih banyak kekurangan dalam penyusunan Karya Tulis Ilmiah, oleh karena itu kritik dan saran yang bersifat membangun sangat penyusun harapkan.

\section{Daftar Pustaka}

Agus Herdiana, 2015, Siklus Hidup Nyamuk Aedes aegypti, http://informasikesling.blogspot.co.id/2015/03/ siklus-hidup-nyamuk-aedes-aegypti.html diakses Tanggal 8 Januari Pukul 15.45 WIB.

Aris Santjaka, 2011, Statistika untuk Penelitian Kesehatan, cetakan pertama, Yogyakarta : Nuha Medika.

- 2013, Pendekatan Model Kausalitas, Malaria, cetakan pertama, Yogyakarta : Nuha Medika.

- 2016, Zika Dalam Prespektif Vektor dan Upaya Pengendaliannya, Purwokerto :Politeknik Kesehatan Semarang Jurusan Kesehatan Lingkungan Purwokerto

Candra Wiguna, 2015, Pencegahan Demam Berdarah Melalui Metode Pemberantasan Sarang Nyamuk (PSN), at http://duniaiptek.com/pencegahan-demamberdarah-melalui-metode-pemberantasansarang-nyamuk-psn/ diakses Tanggal 8 Januari 2017 Pukul 15.41 WIB.

Departemen Kesehatan R.I. Direktorat Pemberantasan Penyakit Bersumber Binatang (DIT. P2B2), (1985), Bagaimana Mencegah Demam Berdarah, Jakarta: DIT.JEN PPM\&PLP.

Departemen Kesehatan R.I, 1986, Direktorat Jenderal PPM\&PLP, Demam Berdarah Dengue Epidemiologi Dan Pemberantasan Di Indonesia, Jakarta: DIT.JEN.PPM\&PLP.

Departemen Kesehatan R.I. Direktorat Jenderal Pengendalian Penyakit Dan Penyehatan Lingkungan(DIT.JEN.PP\&PL), $\quad$ (2013). Pedoman Pengendalian Demam Berdarah Dengue Di Indonesia. Jakarta: DIT.JEN.PP\&PL

Departemen Kesehatan R.I. Direktorat Jenderal Pengendalian Penyakit Dan Penyehatan Lingkungan (DIT.JEN.PP\&PL), 2007, Ekologi Dan Aspek Perilaku Vektor, Jakarta: DIT.JEN. PP\&P 
Fajar Dwi Setyawati, 2009, Karya Tulis Ilmiah "Studi Komparasi Jumlah Telur Nyamuk Aedes Aegypti Pada Ovitrap Yang Dipasang Di Ruang Perawatan Lantai Atas Dengan Lantai Bawah Rsud Prof. Dr. Margono Soekarjo Purwokerto", Purwokerto : Politeknik Kesehatan Semarang Jurusan Kesehatan Lingkungan Purwokerto

Info Kesehatan, 2012, Demam Berdarah: Penyebab, Gejala, Dan Pencegahannya, at http://infokesehatan.net/demam-berdarah-penyebabgejala-dan-pencegahannya/ diakses Tanggal 8 2017 Januari Pukul 16.03 WIB

Irawan Endy Pratama, 2016, Skripsi “Kohort Evaluasi Nyamuk Dewasa Setelah Pelaksanaan Fogging Focus Di Desa Sidamulih Kecamatan Rawalo Kabupaten BanyumasTahun 2016”, Purwokerto : Politeknik Kesehatan Semarang Jurusan Kesehatan Lingkungan Purwokerto

Kementerian Kesehatan R.I Direktorat Jenderal Pengendalian Penyakit dan Penyehatan Lingkungan (Indonesia, (1992), Petunjuk Teknis Pemberantasan Nyamuk Penular Penyakit Demam Berdarah Dengue. Jakarta: DIT.JEN PPM\&PLP.

Kementerian Kesehatan RI, 2016, Wilayah KLB DBD Ada Di 11 Provinsi, Jakarta: KemenkesR.I, at http://www.depkes.go.id/article/print/1603070 0001/wilayah-klb-dbd-ada-di-11-provinsi.htm diaksesTanggal 08 Januari 2017 pukul 15.00

Peraturan Menteri Kesehatan RI No 374/MENKES/PER/III/2010 Tentang pengendalian vector

Riska Alfianastuti, 2015, Pengaruh Pemakaian Perasan Daun Belimbing Wuluh (Averrhoa Bilimbi L.) Terhadap Kematian Larva Aedes Aegypti, Purwokerto : Politeknik Kesehatan Semarang Jurusan Kesehatan Lingkungan Purwokerto

Soedarto, 2012, Demam Berdarah Dengue (Dengue Haemorrahagic Fever), Jakarta : Sagung Seto

Soegijanto, S. (2006). Demam Berdarah Dengue Edisi 2. Surabaya: Airlangga University Press

Tri Cahyono, 2014, Pedoman Penulisan Proposal Penelitian dan Karya Tulis Ilmiah/Skripsi, edisi revisi tiga, Purwokerto : Politeknik Kesehatan Kemenkes Semarang 